International Journal of Engineering \& Technology, $7(3.6)(2018) 264-266$
International Journal of Engineering \& Technology
Website: www.sciencepubco.com/index.php/IJET
Research paper

\title{
E-Gardening Application for Roof Tops Using Android
}

\author{
B. Dwarakanath ${ }^{1 *}$, G. Maria Lynda Missier ${ }^{2}$, S. Madhav ${ }^{3}$, P. Navin ${ }^{4}$ \\ ${ }^{1}$ Assistant Professor, Department Of Information Technology, Hindustan Institute Of Technology And Science, Chennai, Tamil Nadu, \\ India. \\ ${ }^{2}$ Student, Department Of Information Technology, Hindustan Institute Of Technology And Science, Chennai, Tamil Nadu, India. \\ ${ }^{3}$ Student, Department Of Information Technology, Hindustan Institute Of Technology And Science, Chennai, Tamil Nadu, India. \\ ${ }^{4}$ Student, Department Of Information Technology, Hindustan Institute Of Technology And Science, Chennai, Tamil Nadu, India. \\ *Corresponding Author E-Mail:Dwarakanath@Hindustanuniv.Ac.In
}

\begin{abstract}
The gardening field has a very large amount of need to the society as now a day's only the greenery is best for a healthy living. This venture depends on the business exchange of things in a general store. The main movement depends on adding the things to the framework alongside the rate which are available in the market and the name of the things which the store will consist of a basic offer. The admin is in charge of all the data up gradation, deletion and editing. The client need to enter his/her details to login and to view and to request for the requirement and send the request [2].
\end{abstract}

\section{Introduction}

In the recent statistics as everyone is interested in setting up a garden in their own houses for healthy living and is much organized [1] [7]. As the society is become bigger and larger here many of the buildings are build with less space in the front so they might not get disappointed as they couldn't set up a garden and plant trees. The garden can be is set up according to their needs even in a small square feet of about $150 \mathrm{sq}$. ft. too [14]. That's why the roof top garden is set up to help the people to get rid of disappointment and compared to the regular garden the rooftop is much more healthier and helps to analyze the requirements and analyze the personal needs and even for a natural and a healthy living the roof garden can u used [5]. In this method what is actually done is an android web application is created and then there are two faces one is the admin and the client [6]. Here the admin uploads, edits, deletes the details which are to be shown to the client side. Here the client has to login to the application by using the name, mobile number, OTP generation and its according to their will [8]. Once if registered there is no need to re-register again the same details can be used to login again. Once after the verification process is done then the client is allowed to login into the page and then view the partners linked (nurseries) with the application and let's to choose which is best according to the requirement and needs [10].

After viewing the nurseries the clients can choose the appropriate details in the form of a text box where the details are uploaded and then analyzed [6]. Then, the client can send request to the admin regarding the requirement for a roof top garden set up and to analyze that the details sent is according to the clients needs and requirement and the satisfaction is very much important [9]. So once the admin receives the request then the admin will analyze the proper requirement from the client side and then send the details according to it to the client. Therefore, there occurs a client to admin interaction and the process is completed. It incorporates the two deals and buy of things [8]. The task E-Gardening is produced with the goal of making the framework dependable, quick, and more enlightening [12]. There is a considerable measure of explanation behind the presentation of this venture In the manual System, there are number of wasteful aspects that a sales person faces. Substantial must be kept up where applicable and insignificant data must be put away which is extremely chaotic and awkward process [7]. In any case, our System decreases paper takes a shot at the other hand; there are numerous inherent problems that exist in any manual framework [10]. For the most part, they need effectiveness. Less efficiency greatly affects the profitability of any individual staying up with the latest. The predominance of shrewd cell phones has advanced the notoriety of versatile [11]. The application it can store the related data to cloud. To concern administrator to transfer the result of our points of interest and we can store and view the worry client of my watcher the proposed level undertaking the current level of venture full and completely is physically called as the EGardening [13]. One of the problem faced by people living in cities is lack of time. Many people have gardens in their homes. Maintenance of these gardens is tedious and time consuming task $\{14]$.

\section{Existing System}

In the current existing system it is in the form of the data entry in the ledgers, books and all things like that. Everything is hand done and manually it is analyzed and calculated and maintained. These details are being processed and sent through various verification methods and cross checking and such similarities [14]. The existing system is not much useful in the current stage for the reason that people have their priorities and commitments hence it leads to having very minimum time to calculate and write their details in ledger books and so on. Hence, it is being analyzed according to their own way and rectified. Many cheatings and frauds cannot be recognized [13]. A mechanism is to be present, proper procedure to implement them and to analyze them. In this method it normally takes a lot of time to travel and then reach the proper destination. That to may be in a day we can visit only to one spot and for cross checking the details it might take another 
day [12]. Much more time is being required to do this current methodology. Data's are being driven and analyzed only after the booking of them. So this method cannot be useful to all working and social people cause time is very important in today's life.

\section{Disadvantages of Existing System}

- Consume a lot of time.

- At times the books and data's noted are being lost.

- Not safe to store records.

- Not suggested to all.

\section{E-garden System}

Here, this method is totally opposite to the current existing system cause where all the data's, information, products sold are put up and accounted manually here it is done electronically. There is no need for managing them in the form of book or ledger or others. This proposed system is full based on electronic gardening in other words "e-gardening". From the data uploading, editing, deleting giving the proper details to the customer everything is done automatically and it is all done electronically. Even the conversation is done electronically. This is a very simple method and saves a lot of time [13]. The venture depends on the business exchange and charging of things in a general store. The main movement depends on adding the things to the framework alongside the rate which are available in the market and the name of the things which the store will consent to offer. This specialist is offered just to administrator or overseer. Any alterations to be done in the thing name and the rate should be possible just by administrator. He additionally has the privilege to erase any thing[14]. As the client purchases the items and goes to the charging counter, the client should enter the thing name he acquired and the amount of the thing he had obtained. This isn't a tremendous an assignment. If interested the contract based gardening is also suggested where a contract is signed between the client and the admin for about 1month to 12 months (one year) and fully from sand maintenance, pesticides, watering accordingly, fertilizers all are initialized and processed completely.

\subsection{Architecture of E-Garden System}

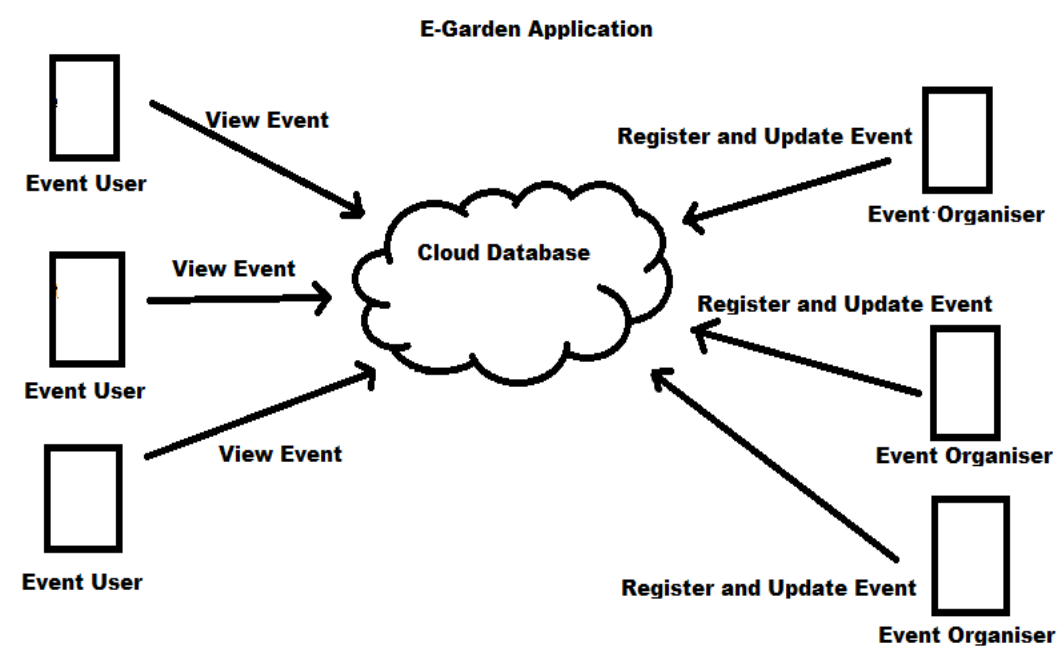

Figure 1: Architecture of E-garden application

This is how the process is done and all the data's are stored in the cloud and it is being retrieved only when it is required and the operation is done electronically only the request and response is being done manually. All the others are done electronically only.

\section{2. $\mathrm{S}$}

Table 1: Plantation and Maintenance Per Area in sq. $\mathrm{ft}$

\begin{tabular}{|l|l|l|}
\multicolumn{4}{|c|}{ Table 1: Plantation and Maintenance Per Area in sq. ft } \\
\begin{tabular}{|l|l|l|}
\hline Square Feet & \multicolumn{1}{|c|}{150 SQ FT } & 500 SQ FT \\
\hline Plantation & $\begin{array}{l}\text { There can be more than } \\
4 \text { varieties of fruits, } \\
\text { vegetables and flowers. }\end{array}$ & $\begin{array}{l}\text { Here a large garden with } \\
\text { more than 10 varieties each } \\
\text { can be planted. }\end{array}$ \\
\hline Maintenance & $\begin{array}{l}\text { Must be watered and } \\
\text { taken care in proper } \\
\text { temperature. }\end{array}$ & $\begin{array}{l}\text { Must be watered regularly } \\
\text { and maintained properly, }\end{array}$ \\
\hline
\end{tabular}
\end{tabular}

\subsection{Advantages of E-Garden System}

The mobile application can be used in travel too. The application has proved to be cost and time efficient. The application is user friendly and doesn't require much space or memory.

\section{Results and Discussion}

The application has improved the performance and reduces time of the clients and vendors with the administrator to give an solution to implement roof top gardens with e-garden.

Table 2: Types of plants per area in sq. $\mathrm{ft}$

\begin{tabular}{|l|l|l|l|l|}
\hline $\begin{array}{l}\text { Square } \\
\text { Feet }\end{array}$ & $150 \mathrm{SQFT}$ & 300 SQFT & 500SQFT & 1000 SQFT \\
\hline Fruits & $\begin{array}{l}3-4 \\
\text { varieties }\end{array}$ & $\begin{array}{l}6-8 \\
\text { varieties }\end{array}$ & $\begin{array}{l}10 \\
\text { varieties }\end{array}$ & $\begin{array}{l}\text { Max 20 } \\
\text { varieties }\end{array}$ \\
\hline Vegetables & $\begin{array}{l}3-4 \\
\text { varieties }\end{array}$ & $\begin{array}{l}6-8 \\
\text { varieties }\end{array}$ & $\begin{array}{l}10 \\
\text { varieties }\end{array}$ & $\begin{array}{l}\text { Max 20 } \\
\text { varieties }\end{array}$ \\
\hline Flowers & $\begin{array}{l}3-4 \\
\text { varieties }\end{array}$ & $\begin{array}{l}6-8 \\
\text { varieties }\end{array}$ & $\begin{array}{l}10 \\
\text { varieties }\end{array}$ & $\begin{array}{l}\text { Max 20 } \\
\text { varieties }\end{array}$ \\
\hline
\end{tabular}

Here, a rough calculation is given and according to this only then the plotting can be separated and then analyzed. Many varieties of flowers and vegetables can be planted and analyzed.

\section{Conclusion}

In the existing system if $\mathrm{u}$ refer it takes a lot of time and the process is very long and require proper maintenance if not it is not acceptable. So, to avoid those situations we need to use the electronic garden which manages all the files and stores and analyze them only when required and so we use the e-gardening to 
maintain and manage the garden with the ferns and the maintenance.

\section{Future Scope}

This electronic application can be viewed and then in future it can be hosted in the cloud cause it has a good market in the current statistics of life. The implementation can be done and managed in a proper format and analyzed in the designing and creation of the web application and so on referring the recent statistic at that moment.

\section{References}

[1] Akyildiz IF, Ho JSM \& Lin YB, "Movement-based location update and selective paging for PCS networks", IEEE/ACM Transactions on Networking, Vol.4, No.4, (1996), pp.629-638.

[2] Wang X, Lei X, Fan P, Hu RQ \& Horng S, "Cost Analysis of Movement-Based Location Management in PCS Networks: An Embedded Markov Chain Approach", IEEE Transactions Vehicular Technology, Vol.63, No.4, (2014), pp.1886-1902.

[3] Rose C \& Yates R, "Minimizing the average cost of paging and registration: a timer-based method", Wireless Networks, Vol.2, No.2, (1996), pp.109-116

[4] $\mathrm{Li} \mathrm{K}$, "Analysis of cost and quality of service of time-based dynamic mobility management in wireless networks", Wireless Networks, Vol.20, No.2, (2014), pp.261-288.

[5] Bar-Noy A, Kessler I \& Sidi M, "Mobile users: to update or not to update?", Wireless Networks, Vol.1, No.2, (1995), pp.175-185.

[6] Li K, "Analysis of Distance-Based Location Management in Wireless Communication Networks", IEEE Transactions on Parallel and Distributed Systems, Vol.24, No.2, (2013), pp.225238.

[7] Liang B \& Haas ZJ, "Predictive distance-based mobility management for multidimensional PCS networks", IEEE/ACM Transactions on Networking, Vol.11, No.5, (2003), pp.718-732.

[8] Chen R, Yuan S \& Zhu J, "A dynamic location management method of personal communication system", E-Tech,(2004), pp.1-9.

[9] Ng CK \& Chan HW, "Enhanced Distance-Based Location Management of Mobile Communication Systems Using a Cell Coordinates Approach", IEEE Transactions on Mobile Computing, Vol.4, No.1, (2005), pp.41-55.

[10] Zhu Y \& Leung VCM, "Derivation of moving distance distribution to enhance sequential paging in distance-based mobility management for PCS networks", IEEE Transactions on Wireless Communications, Vol.5, No.11, (2006), pp.3029-3033.

[11] Zhou J, Leong H, Lu Q \& Lee K, “Optimizing Update Threshold for Distance-based Location Tracking Strategies in Moving Object Environments", WOWMOM, (2007), pp.1-8.

[12] Zhu Y \& Leung VCM, "Optimization of Distance-Based Location Management for PCS Networks", IEEE Transactions on Wireless Communications, Vol.7, No.9, (2008), pp.3507-3516.

[13] Zhao QL, Liew SC \& Yu Y, "Location Update Cost of DistanceBased Scheme for PCS Networks with CTRW model", IEEE Communications Letters, Vol.13, No.2, (2009), pp.408-410.

[14] Tripathy AK \& Vichare A, "Open Source Hardware Based Automated Gardening System Using Low-Cost Soil Moisture Sensor", IEEE Xplore, (2015). 